\title{
Mortality study of fertiliser manufacturers in Iceland
}

\author{
V Rafnsson, H Gunnarsdóttir
}

\begin{abstract}
A retrospective cohort study was carried out on workers in a fertiliser plant to assess the risk of stomach and lung cancer. The cohort comprised 603 subjects and their death rates were compared with those of the general male population in Iceland. The study period was 1954 to 1985 . The results do not provide evidence of an excess of deaths from stomach or lung cancer. Total mortality was lower than expected and even lower when the analysis was restricted to those who had worked at the plant for more than one year. Shiftwork operators had the highest SMRs for all cancers, however, with a reverse dose response according to duration of employment, indicating that this might be due to factors unrelated to manufacture of fertilisers. As examples of these factors life style and social class may be implicated, as well as possible selection of weaker subjects to do this assumed easy work.
\end{abstract}

Bacterial action in saliva reduces nitrate to nitrite. Under acidic conditions in vivo nitrites nitrosate amines and amides to form $\mathrm{N}$-nitrosamines, which have been shown to cause cancer in laboratory animals. ${ }^{1}$ It has not been demonstrated that these compounds are carcinogenic in humans, but if they are, it is suggested that the stomach is the target organ. ${ }^{23}$ The use of nitrate fertiliser has increased greatly in the last decades. More nitrate in the soil has led to increased concentrations of nitrate in drinking water and vegetables world wide. At the same time, mortality from stomach cancer has declined in many locations, including Iceland. ${ }^{45}$ Vitamins $\mathrm{C}$ and $\mathrm{E}$ and certain phenols inhibit the formation of $\mathrm{N}$ nitrosamines, whereas other phenols, thiocyanate, and iodide ion catalyse nitrosation. ${ }^{167}$ Other factors, such as diet and social class, have also been considered in connection with gastric cancer. ${ }^{48}$

Investigators have tried to establish whether there is a link between nitrate ingestion and stomach cancer, but have not reached a consensus of opinion;

Department of Occupational Medicine, Administration of Occupational Safety and Health, Bíldshöfdi 16, 110 Reykjavík, Iceland

V Rafnsson, H Gunnarsdóttir some have found a connection between the two, ${ }^{9-15}$ but others have not. ${ }^{16-18}$ In a cohort study of fertiliser manufacturers Fraser et al found a non-significant excess of cancers of the lung and digestive tract in one of two cohorts, ${ }^{1920}$ but concluded that this was probably not related to exposure to nitrate. The conclusion was based on the failure to find an excess mortality from gastric cancer, and contradictory dose response relations for all cancers and cancer of digestive organs. Al-Dabbagh et al conducted a cohort study of fertiliser workers from northern England. ${ }^{21}$ Their results also weighed against the idea that exposure to nitrates leads to cancer. Studies of workers in phosphate fertiliser production and in the phosphate industry in the United States showed no special health risk. The number of deaths from lung cancer was somewhat higher than expected, but the authors found more likely explanations for this than exposure to phosphates. ${ }^{22-24}$

In the light of this information, it was thought worthwhile to examine whether or not employees of a plant producing nitrogen fertiliser and compound fertiliser were more likely to die of cancer, especially of the stomach and lung, than other Icelandic men.

\section{Material and methods}

The fertiliser plant studied produces ammonia and nitric acid from nitrogen and hydrogen. The product is used to make damp ammonium nitrate granules that are then dried and coated, making a special kind of fertiliser. A compound fertiliser (nitrogen, potassium, phosphate) is also produced by combining phosphate and potassium salts with the ammonium nitrate solution during production of the granules. The fertiliser granules were coated with diatome until 1978, when this was replaced with shell lime.

Dust concentrations were measured in the factory in 1978. The results of measurements of respirable dust ranged between $0 \cdot 29-35.09 \mathrm{mg} / \mathrm{m}^{3}$ with a mean value of $1.81 \mathrm{mg} / \mathrm{m}^{3}$ in 29 personal samples for unskilled workers. For shiftwork operators the range was $0.09-3.59 \mathrm{mg} / \mathrm{m}^{3}$ (mean $0.69 \mathrm{mg} / \mathrm{m}^{3}$ ) in 30 personal samples. ${ }^{25}$ Total dust concentrations for unskilled workers were $2 \cdot 16-520 \cdot 80 \mathrm{mg} / \mathrm{m}^{3}$ (mean $96.17 \mathrm{mg} / \mathrm{m}^{3}$ ) in 12 personal samples. At the same time, ammonia in the air where the shiftwork operators were employed measured $0-5 \mathrm{ppm}$ and nitrogen dioxide $0-4 \mathrm{ppm} .{ }^{25}$ In 1985 the respirable dust concentrations were $0.08-2.73 \mathrm{mg} / \mathrm{m}^{3}$ (mean 
$\left.0.63 \mathrm{mg} / \mathrm{m}^{3}\right)$ in 29 personal samples for unskilled workers and $0.07-0.59 \mathrm{mg} / \mathrm{m}^{3}$ (mean $0.26 \mathrm{mg} / \mathrm{m}^{3}$ ) in nine samples for shiftwork operators. ${ }^{26}$ Total dust concentrations for unskilled workers ranged between $1.56-492.90 \mathrm{mg} / \mathrm{m}^{3}$ (mean $65.89 \mathrm{mg} / \mathrm{m}^{3}$ ) in 17 personal samples.

The dust measurements were not done for the purpose of this mortality study. On both occasions they were performed to evaluate the most dusty tasks in the plant and not to describe the total exposure of the employees. The composition of the dust was not differentiated. According to an estimate of the product manager the dust concentrations in the period 1972-8 were similar to those in 1978 but before 1972 were lower than those in 1985 .

The cohort comprised 603 men who were hired during 1954-85 (production started in 1954). The payroll for the years 1954 and 1955 contained no details of employees who had worked less than a year, which may mean that some men are missing. The cumulated employment years were calculated so that any employment on a calendar year counted as one year. Few women were employed and they were omitted. Seventy members of the cohort had died, and information on cause of death was obtained in all cases from the Statistical Bureau of Iceland. From the payroll it was possible to divide the cohort by the jobs on which they were employed into three categories: shiftwork operators, unskilled workers, and others. Shiftwork operators work indoors in three shifts, day and night. Their work is monotonous, mostly operating machinery and their tasks are similar all year round. Unskilled workers perform general labour, mainly out of doors. Their work varies according to season and assignment. The group "others" includes craftsmen and office workers.

This is a retrospective cohort study with a design similar to that used in other mortality studies. ${ }^{27} 28$ Through the personal number and date of birth, it was possible to identify and trace all the living subjects in the national register and those who had died were found through the register of deceased; both of these registers are kept at the Statistical Bureau of Iceland. In this way the vital state of the study population was ascertained for all subjects. Death certificates were obtained and thereby the officially classified underlying cause of death. Different revisions of the International Classification of Diseases (ICD) have been in use during the period of study. The certificated cause of death has been reclassified according to the seventh revision ${ }^{29}$ as the Cancer Register in Iceland uses this revision. ${ }^{5}$

The expected number of deaths was calculated on the basis of person-years of observation within five year age categories during respective single calendar years of the study period, multiplied by the cause and calendar year specific death rates for Icelandic men. The ratio between observed and expected numbers, the standardised mortality ratio (SMR), was calculated with $95 \%$ confidence intervals $(95 \% \mathrm{CI}$ ) assuming a Poisson distribution.

Separate analyses were done on subcohorts according to year when hired and job categories. The calculation of the SMR, when the subcohort of shift work operators was divided according to cumulated years of employment, was done with and without a requirement of a latent period of 15 years. By requiring 15 years latency the effect of the selection of subjects into different exposure groups has been eliminated..$^{30}$ Table 1 shows the number of subjects, person-years, and deaths among the workers in the total cohort and the subcohorts.

Permission was obtained from The Data Protection Commission to compare the datafiles in this study.

Table 1 Number of workers, person-years, and deaths in total cohort and in different subcohorts

\begin{tabular}{|c|c|c|c|c|}
\hline Groups & Study period & No of subjects & $\begin{array}{l}\text { No of } \\
\text { person-years }\end{array}$ & No of deaths \\
\hline $\begin{array}{l}\text { Total cohort: } \\
\text { Hired before } 1963 \\
\text { Hired 1964-73 } \\
\text { Hired after } 1974\end{array}$ & $\begin{array}{l}1954-85 \\
1954-85 \\
1964-85 \\
1974-85\end{array}$ & $\begin{array}{l}603 \\
206 \\
145 \\
252\end{array}$ & $\begin{array}{l}8804 \cdot 5 \\
5121 \cdot 5 \\
2459 \cdot 5 \\
1223 \cdot 5\end{array}$ & $\begin{array}{r}70 \\
51 \\
18 \\
1\end{array}$ \\
\hline $\begin{array}{l}\text { Worked more than one yea } \\
\text { Total cohort } \\
\text { Shiftwork operators } \\
\text { Unskilled workers } \\
\text { Others }\end{array}$ & $\begin{array}{l}1954-85 \\
1954-85 \\
1954-85 \\
1954-85\end{array}$ & $\begin{array}{r}421 \\
160 \\
191 \\
70\end{array}$ & $\begin{array}{l}6893 \cdot 5 \\
3306 \cdot 0 \\
2385 \cdot 0 \\
1202 \cdot 5\end{array}$ & $\begin{array}{r}54 \\
34 \\
15 \\
5\end{array}$ \\
\hline $\begin{array}{l}\text { Shiftwork operators (all) } \\
\text { Employed } \leqslant 1 \text { y } \\
\text { Employed 2-5 y } \\
\text { Employed 6-15 y } \\
\text { Employed } \geqslant 16 \text { y }\end{array}$ & $\begin{array}{l}1954-85 \\
1956-85 \\
1956-85 \\
1954-85 \\
1954-85\end{array}$ & $\begin{array}{r}211 \\
51 \\
47 \\
46 \\
67\end{array}$ & $\begin{array}{r}4376 \cdot 0 \\
1070 \cdot 0 \\
876 \cdot 5 \\
760 \cdot 5 \\
1669 \cdot 0\end{array}$ & $\begin{array}{r}43 \\
9 \\
8 \\
11 \\
15\end{array}$ \\
\hline $\begin{array}{l}\text { Latency of } 15 \text { years: } \\
\text { Shiftwork operators (all) } \\
\text { Employed } \leqslant 1 \mathrm{y} \\
\text { Employed } 2-5 \mathrm{y} \\
\text { Employed 6-15 y } \\
\text { Employed } \geqslant 16 \mathrm{y}\end{array}$ & $\begin{array}{l}1967-85 \\
1971-85 \\
1971-85 \\
1967-85 \\
1967-85\end{array}$ & $\begin{array}{r}169 \\
45 \\
32 \\
25 \\
67\end{array}$ & $\begin{array}{r}1517 \cdot 5 \\
345 \cdot 0 \\
280 \cdot 0 \\
193 \cdot 5 \\
699 \cdot 0\end{array}$ & $\begin{array}{r}25 \\
5 \\
2 \\
3 \\
15\end{array}$ \\
\hline
\end{tabular}




\section{Results}

There were fewer deaths than expected in the cohort: as a whole (table 2). The SMR for stomach cancer was 93 but there was an excess of observed deaths recorded for lung cancer and cancer of the colon, rectum, and pancreas. An excess of observed deaths was recorded for ischaemic heart disease (SMR 103) and accidents (SMR 130). The SMR for all other causes of death was 33 (95\% CI 9-85).

Table 3 shows the SMR for all causes of death, all cancers, and ischaemic heart disease when the cohort was subdivided according to the year when hired. The observed number of deaths was higher than expected in the first group for cancers and ischaemic heart disease and in the second group for ischaemic heart disease.

Table 4 shows the results when the cohort was subdivided according to job categories and restricted to those who had worked for more than one year. The observed deaths were higher than expected for cancer and heart diseases among shiftwork operators. There was a significant deficit for all causes of death among unskilled workers (SMR 60) and the total cohort (SMR 73).

Table 5 shows duration of employment and mortality for shiftwork operators. The SMR for all causes of death and cancer was highest among those who had worked the shortest time, declining with the number of years of employment completed. The SMR for all cancers in the group which had shortest duration of employment was 412 . There were inverse gradients for increasing duration of exposure and mortality both with regard to all cancers and all causes. The SMR for heart disease varied independently of duration of employment.

Table 5 also shows duration of employment and mortality for shiftwork operators, with a requirement of 15 years of latency. For all cancers the inverse gradients in risk were clearer than in the analysis without a requirement of latency, and the SMR for those with the shortest duration of employment rose to 789 .

Table 2 Observed (Obs) and expected (Exp) number of deaths, SMR, and 95\% CI among 603 fertiliser workers

\begin{tabular}{|c|c|c|c|}
\hline Cause of death (ICD, 7 th revision) & Obs & $\operatorname{Exp}$ & $\operatorname{SMR}(95 \% \mathrm{CI})$ \\
\hline $\begin{array}{l}\text { All causes (001-E985) } \\
\text { Malignant neoplasms }(140-205) \\
\text { Stomach }(151) \\
\text { Large intestine }(152,153) \\
\text { Rectum }(154) \\
\text { Pancreas }(157) \\
\text { Trachea, bronchus, and lung }(162,163) \\
\text { Other neoplasms } \\
\text { Cerebrovascular diseases }(330-334) \\
\text { Ischaemic heart disease }(420) \\
\text { Respiratory diseases }(470-527) \\
\text { Accidents, poisonings, and violence (E800-E985) } \\
\text { All other causes }\end{array}$ & $\begin{array}{r}70 \\
17 \\
4 \\
2 \\
1 \\
3 \\
4 \\
3 \\
5 \\
29 \\
2 \\
13 \\
4\end{array}$ & $\begin{array}{r}81 \cdot 40 \\
18 \cdot 59 \\
4 \cdot 32 \\
1.25 \\
0.61 \\
1.31 \\
2 \cdot 88 \\
8 \cdot 47 \\
7 \cdot 08 \\
28.06 \\
5 \cdot 62 \\
9.98 \\
12.07\end{array}$ & $\begin{array}{l}86(67-109) \\
91(53-146) \\
93(25-237) \\
160(19-578) \\
164(4-913) \\
229(47-669) \\
139(38-356) \\
35(7-104) \\
71(23-165) \\
103(69-148) \\
36(4-129) \\
130(69-223) \\
33 *(9-85)\end{array}$ \\
\hline
\end{tabular}

${ }^{\star} \mathrm{p}<0.05$, two tailed.

Table 3 Observed (Obs) and expected (Exp) number of deaths and SMR according to time when hired

\begin{tabular}{|c|c|c|c|c|c|c|c|c|c|}
\hline \multirow[b]{3}{*}{ Cause of death (ICD, 7 th revision) } & \multicolumn{9}{|c|}{ Time when hired (calendar years) } \\
\hline & \multicolumn{3}{|c|}{$1954-63(n=206)$} & \multicolumn{3}{|c|}{$1964-73(n=145)$} & \multicolumn{3}{|c|}{$1974-85(n=252)$} \\
\hline & Obs & $\operatorname{Exp}$ & $S M R$ & Obs & $\operatorname{Exp}$ & $S M R$ & Obs & $\operatorname{Exp}$ & $S M R$ \\
\hline $\begin{array}{l}\text { All causes } \\
\text { Malignant neoplasms } \\
\text { Ischaemic heart disease }\end{array}$ & $\begin{array}{l}51 \\
14 \\
21\end{array}$ & $\begin{array}{l}56 \cdot 26 \\
12 \cdot 76 \\
19 \cdot 26\end{array}$ & $\begin{array}{r}91 \\
110 \\
109\end{array}$ & $\begin{array}{r}18 \\
3 \\
8\end{array}$ & $\begin{array}{r}21 \cdot 58 \\
5 \cdot 07 \\
7 \cdot 71\end{array}$ & $\begin{array}{r}83 \\
59 \\
104\end{array}$ & $\begin{array}{l}1 \\
\mathbf{0} \\
\mathbf{0}\end{array}$ & $\begin{array}{l}3.56 \\
0.75 \\
1.09\end{array}$ & - \\
\hline
\end{tabular}

Table 4 Observed (Obs) and expected (Exp) number of deaths and SMR in the job categories and in the total cohort among those who had worked for more than one year

\begin{tabular}{|c|c|c|c|c|c|c|c|c|c|c|c|c|}
\hline \multirow{2}{*}{$\begin{array}{l}\text { Cause of death } \\
\text { (ICD, 7th revision) }\end{array}$} & \multicolumn{3}{|c|}{ Shiftwork operators $(n=160)$} & \multicolumn{3}{|c|}{ Unskilled workers ( $n=191)$} & \multicolumn{3}{|c|}{ Others $(n=70)$} & \multicolumn{3}{|c|}{$A l l(n=421)$} \\
\hline & Obs & $\operatorname{Exp}$ & $S M R$ & Obs & $\operatorname{Exp}$ & $S M R$ & Obs & $\operatorname{Exp}$ & $S M R$ & Obs & $\operatorname{Exp}$ & $S M R$ \\
\hline $\begin{array}{l}\text { All causes } \\
\text { Malignant neoplasms } \\
\text { Ischaemic heart disease }\end{array}$ & $\begin{array}{l}34 \\
10 \\
17\end{array}$ & $\begin{array}{r}37 \cdot 78 \\
9 \cdot 01 \\
13 \cdot 57\end{array}$ & $\begin{array}{r}90 \\
111 \\
125\end{array}$ & $\begin{array}{r}15 \\
2 \\
6\end{array}$ & $\begin{array}{r}25 \cdot 04 \\
5 \cdot 80 \\
8 \cdot 93\end{array}$ & $\begin{array}{l}60^{\star} \\
34 \\
68\end{array}$ & $\begin{array}{l}5 \\
0 \\
3\end{array}$ & $\begin{array}{r}11 \cdot 22 \\
2 \cdot 28 \\
3 \cdot 66\end{array}$ & $\frac{45}{82}$ & $\begin{array}{l}54 \\
12 \\
26\end{array}$ & $\begin{array}{l}74 \cdot 03 \\
17 \cdot 10 \\
26 \cdot 06\end{array}$ & $\begin{array}{l}73^{\star} \\
70 \\
100\end{array}$ \\
\hline
\end{tabular}

${ }^{\star} \mathrm{p}<0.05$, two tailed. 
Table 5 Observed (Obs) and expected (Exp) numbers of deaths and SMR by duration of employment as a shiftwork operator without and with requirement of 15 years latency

\begin{tabular}{|c|c|c|c|c|c|c|c|c|c|c|c|c|c|c|c|}
\hline \multirow{3}{*}{$\begin{array}{l}\text { Cause of death } \\
\text { (ICD, 7th revision) }\end{array}$} & \multicolumn{15}{|c|}{ Duration of employment (y) } \\
\hline & \multicolumn{3}{|c|}{$\leqslant 1(n=51)$} & \multicolumn{3}{|c|}{$2-5(n=47)$} & \multicolumn{3}{|c|}{$6-15(n=46)$} & \multicolumn{3}{|c|}{$\geqslant 16(n=67)$} & \multicolumn{3}{|c|}{ All $(n=211)$} \\
\hline & $O b s$ & $\operatorname{Exp}$ & $S M R$ & Obs & $\operatorname{Exp}$ & $S M R$ & Obs & $\operatorname{Exp}$ & $S M R$ & Obs & $\operatorname{Exp}$ & $S M R$ & Obs & $\operatorname{Exp}$ & $S M R$ \\
\hline \multicolumn{16}{|l|}{ Without latency time: } \\
\hline All causes & 9 & $4 \cdot 74$ & 190 & 8 & 4.53 & 177 & 11 & $12 \cdot 48$ & 88 & 15 & $20 \cdot 77$ & 72 & 43 & 42.51 & 101 \\
\hline Malignant neoplasms & 4 & 0.97 & $412^{\star}$ & 2 & 0.99 & 202 & 5 & 2.93 & 171 & 3 & 5.09 & 59 & 14 & 9.98 & 140 \\
\hline Ischaemic heart disease & 1 & $1 \cdot 30$ & 77 & 4 & $1 \cdot 47$ & 272 & 6 & $4 \cdot 48$ & 134 & 7 & $7 \cdot 62$ & 92 & 18 & $14 \cdot 87$ & 121 \\
\hline \multicolumn{16}{|l|}{ With 15 years latency: } \\
\hline All causes & 5 & $1 \cdot 86$ & 269 & 2 & $2 \cdot 24$ & 89 & 3 & $5 \cdot 56$ & 53 & 15 & $13 \cdot 81$ & 109 & 25 & $23 \cdot 46$ & 107 \\
\hline Malignant neoplasms & 3 & $0 \cdot 38$ & 789* & 1 & 0.54 & 185 & 2 & 1.29 & 155 & 3 & $3 \cdot 42$ & 88 & 9 & $5 \cdot 64$ & 160 \\
\hline Ischaemic heart disease & 0 & 0.56 & - & 1 & 0.86 & 116 & 1 & 1.99 & 50 & 7 & $5 \cdot 44$ & 129 & 9 & $8 \cdot 84$ & 102 \\
\hline
\end{tabular}

${ }^{\star} \mathrm{p}<0.05$, two tailed.

\section{Discussion}

The objective of our study was to see whether men working in fertiliser production had an excess risk of dying of cancer, especially of the stomach and lung. The results do not allow us to give a definite answer.

There are some weaknesses in the study. For instance, the cohort is compared with the entire Icelandic male population and not with other working men, and this comparison invites the "healthy worker effect." results regarding gastric and lung cancer would only be obtained with a risk of at least three times that of the general population.

The possible relation between consumption of nitrate and stomach cancer has been discussed. It was therefore decided to study the mortality from gastric cancer in the cohort at the outset, even though it was not a question of actual ingestion of nitrates, but rather of exposure to dust that could enter the lungs or mouth. On this basis it was considered appropriate to study lung cancer as well.

The results do not indicate that exposure to nitrate during fertiliser manufacturing leads to excess risk of dying from gastric or lung cancer and are in agreement with the findings of Al-Dabbagh et $a l^{1}$ and Fraser $e t a l .{ }^{1920}$ As in the results of Fraser $e t$ al the highest risk of cancer was found in a group exposed to the least amount of nitrogen fertiliser. This inverse dose response relation indicates that the explanation is not to be found in the environment of work. The causes are, however, not clear.

A possible explanation may relate to selection. According to information from the plant the task and the work setting for the shiftwork operators were assumed by the workers themselves to be convenient, which might have caused a selection of weaker subjects to that job category.

Studies of fertiliser plant employees have discussed the possible importance of lifestyle and social class; ${ }^{19}$ those from England and Wales showed that mortality ratios from cancer vary according to social class. ${ }^{32}$ Social divisions in Iceland are said to be primarily based on educational rather than economic grounds. ${ }^{33}$ Whether lifestyle and educational factors connected with the social classes play an important part in the explanation of cancer mortality in Iceland is not yet known.

We thank Vídir Kristjánsson, head of the Department of Industrial Hygiene at the Administration of Occupational Safety and Health and Runólfur Thórdarson, product manager at the plant for valuable information and help.

1 Flamm WG. Nitrates. In: Wald NJ, Doll R, eds. Interpretation of negative epidemiological evidence for carcinogenicity. Lyon and Oxford: International Agency for Research on Cancer and Green College, 1985:181-2.

2 Fraser P. Nitrates. In: Wald NJ, Doll R, eds. Interpretation of negative epidemiological evidence for carcinogenicity. Lyon and Oxford: International Agency for Research on Cancer and Green College, 1985:183-94.

3 Reed PI, Smith PLR, Haines K, House FR, Walters CL. Gastric juice n-nitrosamines in health and gastroduodenal disease. Lancet 1981;ii:550-2.

4 Miller AB. Risk factors from geographic epidemiology for gastrointestinal cancer. Cancer 1982;50:2533-40.

5 Bjarnason Ó, Tulinius H. Cancer registration in Iceland 19551974. Acta Pathol Microbiol Immunol Scand 1983;91: Suppl 281.

6 Mirvish SS. The etiology of gastric cancer. Intragastric nitrosamide formation and other theories. J Natl Cancer Inst 1983;71:630-47.

7 Tannenbaum SR. Nutrition: The Changing Scene. N-nitroso compounds: A perspective on human exposure. Lancet 1983;ii:629-31.

8 Fraser P, Chilvers C, Beral V, Hill MJ. Nitrate and human cancer: A review of the evidence. Int J Epidemiol 1980;9:3-11.

9 Zaldivar R, Robinson H. Epidemiological investigation on stomach cancer mortality in Chileans: Association with nitrate fertiliser. Zeitschrift fuer Krebsforschung und Klinische Onkologie 1973;80:289-95.

10 Hill MJ, Hawksworth G, Tattersall G. Bacteria, nitrosamines and cancer of the stomach. $\mathrm{Br} J$ Cancer 1973;28:562-7.

11 Cuello C, Correa P, Haenszel W, et al. Gastric cancer in Colombia. I. Cancer risk and suspect environmental agents. $J$ Natl Cancer Inst 1976;57:1015-20.

12 Tannenbaum SR, Moran D, Rand W, Cuello C, Correa P. Gastric cancer in Colombia. IV. Nitrite and other ions in 
gastric contents of residents from a high-risk region. $J$ Natl Cancer Inst 1979;62:9-12.

13 Armijo R, Coulson AH. Epidemiology of stomach cancer in Chile-the role of nitrogen fertilisers. Int $J$ Epidemiol 1975;4:301-9.

14 Jensen OM. Nitrate in drinking water and cancer in Northern Jutland, Denmark, with special reference to stomach cancer. Ecotoxicol Environ Safety 1982;6:258-67.

15 Hartman PE. Review: Putative mutagens and carcinogens in foods. I. Nitrate/nitrite ingestion and gastric cancer mortality. Environ Mol Mutagen 1983;5:111-21.

16 Davis JM. Stomach cancer mortality in Worksop and other Nottinghamshire mining towns. Br J Cancer 1980;41:438-45.

17 Armijo R, Gonzalez A, Orellana M, Coulson AH, Sayre JW, Detels R. Epidemiology of gastric cancer in Chile: II - Nitrate exposures and stomach cancer frequency. Int $J$ Epidemiol $1981 ; 10: 57-62$

18 Forman D, Al-Dabbagh S, Doll R. Nitrates, nitrites and gastric cancer in Great Britain. Nature 1985;313:620-5.

19 Fraser $P$, Chilvers C, Goldblatt P. Census-based mortality study of fertiliser manufacturers. Br J Ind Med 1982;39:323-9.

20 Fraser $P$, Chilvers $C$, Day $M$, Goldblatt $P$. Further results from a census based mortality study of fertiliser manufacturers. $\mathrm{Br} \mathrm{J}$ Ind Med 1989;46:38-42.

21 Al-Dabbagh S, Forman D, Bryson D, Stratton I, Doll R. Mortality of nitrate fertiliser workers. $\mathrm{Br} \mathrm{J}$ Ind $\mathrm{Med}$ 1986;43:507-15.

22 Stayner LT, Meinhardt T, Lemen R, et al. A retrospective cohort mortality study of a phosphate fertiliser production facility. Arch Environ Health 1985;40:133-8.
23 Checkoway H, Mathew RM, Hickey JLS, et al. Mortality among workers in the Florida phosphate industry. I. Industry-wide cause-specific mortality patterns. J Occup Med 1985;27: 885-92.

24 Checkoway H, Mathew RM, Hickey JLS, et al. Mortality among workers in the Florida phosphate industry. II. Cause-Specific mortality relationships with work areas and exposures. $J$ Occup Med 1985;27:893-6.

25 Pétursson Ó, Holsvik H, Saemundsson E. Malingar á mengun $i$ andrümslofti starfsmanna Áburðarverksmiojju rikisins. Reykjavik: Heilbrigðiseftirlit rikisins, 1980.

26 Kristjánsson V. Malingar á rykmengun i Áburðarverksmiðju rikisins. Reykjavik: Vinnueftirlit ríkisins, 1985.

27 Rafnsson V, Jóhannesdóttir SG. Mortality among masons in Iceland. Br J Ind Med 1986;43:522-5.

28 Rafnsson V, Gunnarsdóttir H. Mortality among farmers in Iceland. Int J Epidemiol 1989;18:146-51.

29 Manual of the international statistical classification of diseases, injuries, and causes of death. Geneva: WHO, 1957.

30 Swaen GHM, Volovics A. Investigating dose response relations in occupational mortality studies: something to keep in mind. Br J Ind Med 1987;44:642-4.

31 Wen CP, Tsai SP, Gibson RL. Anatomy of the healthy worker effect: A critical review. J Occup Med 1983;25:283-9.

32 Office of Population Censuses and Surveys. Occupational mortality 1970-72; decennial supplement. London: HMSO 1978.

33 Broddason $\mathrm{Th}$, Webb $\mathrm{K}$. On the myth of social equality in Iceland. Acta Sociologica 1975;18:49-61.

Accepted 21 May 1990

\section{Correspondence and editorials}

The British Journal of Industrial Medicine welcomes correspondence relating to any of the material appearing in the journal. Results from preliminary or small scale studies may also be published in the correspondence column if this seems appropriate. Letters should be not more than 500 words in length and contain a minimum of references. Tables and figures should be kept to an absolute minimum. Letters are accepted on the understanding that they may be subject to editorial revision and shortening.

The journal now also publishes editorials which are normally specially commissioned. The Editor welcomes suggestions regarding suitable topics; those wishing to submit an editorial, however, should do so only after discussion with the Editor. 